Pak. j. sci. ind. res. Ser. B: biol. sci. 2016 59(3) 126-132

\title{
Phenology and Yield of Strawberry as Influenced by Planting Time and Genotypes in a Sub Tropical Region
}

\author{
M. Moshiur Rahman*, Madan Gopal Saha, M. Nazirul Islam, \\ M. Azmat Ullah and A.K.M. Quamruzzaman \\ Horticulture Research Centre, Bangladesh Agricultural Research Institute (BARI), Gazipur-1701, Bangladesh \\ (received April 6, 2015; revised June 8, 2016; accepted June 16, 2016)
}

\begin{abstract}
Effects of planting time on phenology of five strawberry genotypes 'Sweet Charlie', 'Festival', 'Camarosa', 'FA 008', and 'BARI strawberry-1' were evaluated at Bangladesh Agricultural Research Institute in two consecutive years 2009-2010 and 2010-2011. 'Sweet Charlie' took the shorter time to begin flowering, followed by 'BARI Strawberry-1' and 'Festival' when planted in $1^{\text {st }}$ October. Genotype 'FA 008 ' took longer time to flower when planted in $1^{\text {st }}$ December. Days to flowering of all the varieties was found to decrease with the increase in air temperature. Regardless of planting year, the genotype 'FA 005 ' followed by 'Camarosa' and 'Festival', planted on $1^{\text {st }}$ September, exhibited the longest harvest duration, while 'Sweet Charlie' planted on $1^{\text {st }}$ December exhibited the shortest harvest duration in both years. Genotype 'Festival' planted on October yielded fruit with the greatest fruit weight, followed by 'Sweet Charlie' and 'Camarosa' planted on the same date. Plants of 'FA 008' and 'BARI Strawberry-1' planted in December produced minimum fruit weight. Maximum number of fruits/plant as well as yield/plant obtained from 'Sweet Charlie' planted in October, while BARI Strawberry-1 planted in December yielded the least. With the use of quadratic equation it was estimated that maximum yield was obtained at ambient temperature $18.5^{\circ} \mathrm{C}$ then it was decreased with the increase of temperature. Strawberry planted in early October was found to be the most suitable in Bangladesh. Among the studied genotypes, 'Sweet Charlie' was found to be superior in yield and early planting, and 'Camarosa' was suitable for late planting. 'Festival' was found less sensitive to planting date.
\end{abstract}

Keywords: phenology, strawberry, planting time, sub tropical region

\section{Introduction}

Strawberry (Fragaria $\times$ ananassa Duch) is a delicious exotic small fruit crop in Bangladesh. It is photo sensitive as well as thermo sensitive. It has adapted to different environmental conditions and being cultivated across the world (Rice, 1990). The cultivars, which are growing in Bangladesh are short day plants. Environmental conditions prevailing during October to March are suitable for growth and development of strawberry (Ahmad and Uddin, 2012). In Bangladesh there is a cycle of six seasons in a year. Environments of each of every two months are significantly different from the other seasons. The temperature in Bangladesh starts decreasing from the second half of October after which the temperature starts to increase until the end of February. Extreme environmental conditions of March are not suitable for strawberry (Ahmad and Uddin, 2012). Daytime temperatures of about $20-26{ }^{\circ} \mathrm{C}$ and night time temperatures of about $12-16{ }^{\circ} \mathrm{C}$, with $8-12$ $\mathrm{h} /$ day length are optimum for higher yields and quality fruits of strawberry (Darnell, 2003). Planting time thus *Author for correspondence; E-mail: moshiur.bari@yahoo.com exposes plants to different growing conditions. High temperature can cause morphological, anatomical, physiological, and biochemical change in plant tissue influencing growth and development of crop (Biscoe and Gallagher, 1978). Early planting encourages vegetative growth. On the other hand late planting exposes plant to high temperature zone of climate cycle which shortens developmental phases and thus reduces yield (Rice, 1990). However, cultivar differences in response to high temperature have not been sufficiently reported. Selection of cultivars is one of the strategies to cope with abiotic climatic stresses like high temperature and change of precipitation pattern (Zheng et al., 2009). Therefore, the present study was undertaken to evaluate cultivars in different planting times to prolong strawberry season in sub-tropical regions like Bangladesh.

\section{Materials and Methods}

Experimental site, design, layout and plant production. The study was conducted on the Fruit Research Farm of the Horticulture Research Centre, Bangladesh Agricultural Research Institute, Gazipur, Bangladesh 
(Latitude $23^{\circ} 59^{\prime} \mathrm{N}$, Longitude $90^{\circ} 24^{\prime} \mathrm{E}$, altitude $14.33 \mathrm{~m}$ ) during the winter seasons of 2009-10 and 2010-11. This region is classified as sub-tropical, having hot summers (May to August) and mild winters (December to February). The cumulative rainfall is about $119 \mathrm{~mm}$ during August to May with an average relative humidity of $82.9 \%$. The mean maximum and minimum temperatures during the cropping period in which the study was conducted were 26.29 and $15.75{ }^{\circ} \mathrm{C}$, respectively. The daily as well as monthly mean weather data were collected, documented and recorded by Physiology Division, Bangladesh Rice Research Institute, Joydebpur, Gazipur, Bangladesh. Monthly mean weather data during the study period of 2009-10 and 2010-11 are shown in Table 1 . The soil on the experimental farm was a clay loam, having a $\mathrm{pH}$ of 6.2 (slightly acidic), with low organic carbon $(0.95 \%)$, phosphorus (9 ppm) and potassium $(0.17 \mathrm{meq} / 100 \mathrm{~g}$ soil).

The experimental design was a strip plot with two treatment factors, viz. genotype and planting date, replicated three times. Genotypes included 'Sweet

Table 1. Monthly mean weather data during the experimental periods for strawberry planted at BARI, Gazipur, Bangladesh (2009-2011)

\begin{tabular}{|c|c|c|c|c|}
\hline \multirow[t]{2}{*}{ Year/Month } & \multicolumn{2}{|c|}{ Temperature $\left({ }^{\circ} \mathrm{C}\right)$} & \multirow{2}{*}{$\begin{array}{l}\text { Relative } \\
\text { humidity } \\
(\%)\end{array}$} & \multirow{2}{*}{$\begin{array}{l}\text { Cumulative } \\
\text { rainfall } \\
(\mathrm{mm})\end{array}$} \\
\hline & $\begin{array}{l}\text { Maxi- } \\
\text { mum }\end{array}$ & $\begin{array}{l}\text { Mini- } \\
\text { mum }\end{array}$ & & \\
\hline \multicolumn{5}{|l|}{ 2009-2010 } \\
\hline August & 27.69 & 22.01 & 87.22 & 463 \\
\hline September & 27.93 & 21.84 & 86.88 & 144 \\
\hline October & 26.79 & 19.30 & 86.31 & 157 \\
\hline November & 25.91 & 15.32 & 80.77 & 15 \\
\hline December & 21.67 & 11.24 & 79.75 & 00 \\
\hline January & 20.10 & 9.35 & 79.25 & 00 \\
\hline February & 23.89 & 11.51 & 71.49 & 15 \\
\hline March & 28.37 & 17.84 & 66.55 & 12 \\
\hline April & 25.94 & 21.21 & 77.46 & 42 \\
\hline May & 28.33 & 20.89 & 78.46 & 234 \\
\hline \multicolumn{5}{|l|}{$2010-2011$} \\
\hline August & 27.69 & 22.40 & 84.93 & 185 \\
\hline September & 26.78 & 21.91 & 87.73 & 64 \\
\hline October & 27.05 & 20.80 & 85.16 & 110 \\
\hline November & 25.33 & 16.04 & 80.88 & 02 \\
\hline December & 21.84 & 11.29 & 79.86 & 53 \\
\hline January & 22.64 & 10.22 & 81.65 & 00 \\
\hline February & 23.64 & 13.42 & 69.33 & 06 \\
\hline March & 28.54 & 16.87 & 67.49 & 15 \\
\hline April & 28.42 & 21.09 & 76.48 & 55 \\
\hline May & 28.77 & 18.66 & 85.31 & 74 \\
\hline
\end{tabular}

Source: Physiology Division, Bangladesh Rice Research Institute, Joydebpur, Gazipur-1701, Bangladesh.
Charlie', 'Festival', 'Camarosa', 'FA 008' and 'BARI Strawberry-1' and planting dates were ' $1{ }^{\text {st }}$ September', ' $1{ }^{\text {st }}$ October', ' $1{ }^{\text {st }}$ November' and ' $1{ }^{\text {st }}$ December'.

The experiment was conducted during the winter seasons of 2009-10 and 2010-11. Four planting times were assigned in the main plot and the five strawberry genotypes were assigned in sub plot. The unit plot size was $100 \times 1000 \mathrm{~cm}$ and the plants were spaced $50 \times$ $40 \mathrm{~cm}$ on beds. The main plot (strip) size for planting time was $2250 \times 1000 \mathrm{~cm}$. A single bed was used as a single treatment. Beds were raised $30 \mathrm{~cm}$ above the ground level with a $50 \mathrm{~cm}$ wide drain between beds. Each plot contained a double row accommodating 50 plants. Thirty ( \pm five) days old samples (daughter plant) of different strawberry genotypes were planted on the four planting dates in 2009 and then again on the same dates in 2010 .

Selected plants of 'Sweet Charlie', 'Festival', 'Camarosa', 'FA 008' and 'BARI Strawberry-1' were planted in nursery beds for multiplication in July-August, 2009 and 2010. After 15 to 20 days, all plants started to produce runners. Runners were two-node horizontal stems, with clonal 'daughter' plants produced at the distal node. The daughter plants were collected and established in poly bags filled with $50 \%$ sterilized sand and $50 \%$ cow dung followed by labeling. The established daughter plants were used as clonal propagules for the experiment. The propagules were categorized according to the age, crown size, shape and number of leaves for each treatment. Thirty to thirty five days old Propagules were selected for planting in the experimental field.

During land preparation well decomposed cow dung, urea, TSP, and MP @ 75 ton, 650 kg, 500 kg and 600 $\mathrm{kg}$ were applied per hectare, respectively. All the cow dung, TSP and half of MP fertilizer were applied during bed preparation. Total urea and rest of MP were applied 20 days interval at 5 equal splits from 15 days after planting. After planting, runners were removed every 3 to 4 days. Straw mulch (2-3 cm thick) was applied around the plants, which is a practice that helps conserve soil moisture, decrease weed growth, and promotes fruit quality by preventing berries from laying on the soil surface. Remaining weeds were removed as needed. Overhead irrigation was given whenever necessary to maintain available soil moisture in the field for better plant growth. All other necessary cultural practices and plant protection measures were followed during the entire period of experiment according to BARI (2011). 
Strawberries were hand harvested every 2 to 3 days and early in the day, when it was cool. The fruits were harvested at commercial maturity, which is when more than $80 \%$ of the fruit surface had turned a red colour. Immediately after harvesting, the strawberries were sorted to eliminate damaged fruit and berries were selected for uniform size and colour for subsequent data collection.

Data were collected from the interior plants within each row to avoid potential border effects. In each sub plot, 40 plants were selected randomly for recording data on different phenological, yield and yield-contributing characters.

Data collected. Days to $50 \%$ flowering was estimated as the number of days required from planting to first flower opening among $50 \%$ of plants per plot. Days to harvest was determined as the number of days required from first flowering to first harvest. Harvest duration was recorded as the number of days required from first fruit harvest to completion of fruit harvest. Total number of harvested fruits was counted from selected 40 plants of each sub plot throughout the harvesting period and the average value of the total number of fruits/plant was counted. Total weight of harvested fruits from select plants were also determined for each plot. Yield per plant was also determined from selected plants.

Data analysis. Data were analyzed using analysis of variance and regression analysis using MSTAT-C program (Russell and Eisenmith, 1983). The mean comparison was done following the Duncan's Multiple Range Test (DMRT).

\section{Results and Discussion}

Days to $\mathbf{5 0 \%}$ flowering. In respect of interaction between genotypes and planting time, 'Sweet Charlie' planted on $1^{\text {st }}$ October took the minimum number of days for flowering, which was 68 days in 2009-10 and 64 days in 2010-11. Similar trend of days to flowering was observed in genotypes 'Sweet Charlie' and 'BARI Strawberry-1' (69 and 67 days in 2009-10 and 2010-11, respectively) and 'Festival' (74 and 68 days in 2009-10 and 2010-11, respectively) planted on the same date. Genotype 'FA 008' planted on $1^{\text {st }}$ December took maximum number of days to flowering in each crop year 2009-10 and 2010-11 (Table 2).

Table 2. Interaction effect of planting time and genotypes on phenological traits of strawberry at 2009-10 and 2010-11

\begin{tabular}{|c|c|c|c|c|c|c|}
\hline \multirow[t]{2}{*}{ Treatment } & \multicolumn{2}{|c|}{ Days to flowering } & \multicolumn{2}{|c|}{ Days to harvest } & \multicolumn{2}{|c|}{ Harvest duration } \\
\hline & $2009-10$ & $2010-11$ & $2009-10$ & $2010-11$ & $2009-10$ & $2010-11$ \\
\hline $1^{\text {st }}$ Sep. $\times$ Sweet Charlie & $81^{\circ}$ & $85^{\operatorname{lmn}}$ & $17^{\text {nop }}$ & $20^{\mathrm{j}-\mathrm{n}}$ & $80^{\mathrm{g}}$ & $87^{\text {cde }}$ \\
\hline $1^{\text {st }}$ Sep. $\times$ Festival & $8^{\mathrm{kl}}$ & $88^{\mathrm{jk}}$ & $20^{i-n}$ & $23^{e-j}$ & $88^{\mathrm{cd}}$ & $93^{\mathrm{b}}$ \\
\hline $1^{\text {st }}$ Sep. $\times$ Camarosa & $87^{\mathrm{kl}}$ & $92^{\text {fgh }}$ & $23^{e-j}$ & $22^{\mathrm{g}-1}$ & $90^{\mathrm{c}}$ & $97^{\mathrm{a}}$ \\
\hline $1^{\text {st }}$ Sep. $\times$ FA 008 & $88^{\mathrm{jk}}$ & $93^{\mathrm{d}-\mathrm{g}}$ & $24^{\mathrm{c}-\mathrm{h}}$ & $26^{\mathrm{b}-\mathrm{f}}$ & $94^{\mathrm{b}}$ & $98^{\mathrm{a}}$ \\
\hline $1^{\text {st }}$ Sep. $\times$ BARI Strawberry-1 & $84^{\mathrm{mm}}$ & $83^{\text {no }}$ & $20^{\mathrm{i}-\mathrm{n}}$ & $18^{\mathrm{mno}}$ & $85^{\mathrm{ef}}$ & $82^{\mathrm{g}}$ \\
\hline $1^{\text {st }}$ Oct. $\times$ Sweet Charlie & $68^{\mathrm{s}}$ & $64^{\mathrm{t}}$ & $21^{\mathrm{h}-\mathrm{m}}$ & $23^{e-j}$ & $80^{\mathrm{g}}$ & $72^{\mathrm{i}}$ \\
\hline $1^{\text {st }}$ Oct. $\times$ Festival & $74^{\mathrm{qr}}$ & $68^{\mathrm{s}}$ & $23^{e-j}$ & $26^{\mathrm{b}-\mathrm{e}}$ & $83^{\mathrm{fg}}$ & $81^{\mathrm{g}}$ \\
\hline $1^{\text {st }}$ Oct. $\times$ Camarosa & $75^{\mathrm{q}}$ & $72^{r}$ & $23^{e-j}$ & $28^{\mathrm{ab}}$ & $85^{\text {def }}$ & $83^{\mathrm{fg}}$ \\
\hline $1^{\text {st }}$ Oct. $\times$ FA 008 & $78^{p}$ & $76^{\mathrm{pq}}$ & $27^{\mathrm{bc}}$ & $31^{\mathrm{a}}$ & $85^{\text {def }}$ & $88^{\text {cde }}$ \\
\hline $1^{\text {st }}$ Oct. $\times$ BARI Strawberry- 1 & $69^{\mathrm{s}}$ & $67^{\mathrm{t}}$ & $23^{e-j}$ & $19^{\mathrm{k}-\mathrm{n}}$ & $81^{\mathrm{g}}$ & $77^{\mathrm{h}}$ \\
\hline $1^{\text {st }}$ Nov. $\times$ Sweet Charlie & $78^{p}$ & $83^{\text {no }}$ & $24^{\mathrm{c}-\mathrm{h}}$ & $18^{\mathrm{mno}}$ & $50^{\mathrm{lm}}$ & $45^{\mathrm{n}}$ \\
\hline $1^{\text {st }}$ Nov. $\times$ Festival & $84^{\mathrm{mn}}$ & $90^{\mathrm{hij}}$ & $23^{e-j}$ & $24^{\mathrm{c}-\mathrm{h}}$ & $53^{\mathrm{k}}$ & $49^{\mathrm{m}}$ \\
\hline $1^{\text {st }}$ Nov. $\times$ Camarosa & $86^{\mathrm{klm}}$ & $91^{\text {ghi }}$ & $22^{\mathrm{g}-\mathrm{k}}$ & $27^{\mathrm{bc}}$ & $54^{\mathrm{jk}}$ & $51^{\mathrm{klm}}$ \\
\hline $1^{\text {st }}$ Nov. $\times$ FA 008 & $88^{\mathrm{jk}}$ & $95^{\mathrm{bcd}}$ & $25^{\mathrm{b}-\mathrm{g}}$ & $30^{\mathrm{a}}$ & $56^{\mathrm{j}}$ & $54^{\mathrm{k} k}$ \\
\hline $1^{\text {st }}$ Nov. $\times$ BARI Strawberry- 1 & $78^{p}$ & $83^{\text {no }}$ & $19^{\mathrm{k}-\mathrm{n}}$ & $22^{\mathrm{g}-\mathrm{k}}$ & $52^{\mathrm{kl}}$ & $49^{\mathrm{m}}$ \\
\hline $1^{\text {st }}$ Dec. $\times$ Sweet Charlie & $88^{\mathrm{jk}}$ & $93^{\mathrm{d}-\mathrm{g}}$ & $15^{\text {opq }}$ & $13^{\mathrm{q}}$ & $32^{\text {op }}$ & $21^{\mathrm{r}}$ \\
\hline $1^{\text {st }}$ Dec. $\times$ Festival & $90^{\mathrm{hij}}$ & $96^{\mathrm{bc}}$ & $15^{\text {opq }}$ & $17^{\text {nop }}$ & $33^{\text {op }}$ & $28^{\mathrm{q}}$ \\
\hline $1^{\text {st }}$ Dec. $\times$ Camarosa & $94^{\mathrm{c}-\mathrm{f}}$ & $97^{\mathrm{b}}$ & $18^{\mathrm{mno}}$ & $17^{\text {nop }}$ & $34^{\circ}$ & $30^{\mathrm{pq}}$ \\
\hline $1^{\text {st }}$ Dec. $\times$ FA 008 & $95^{\mathrm{bcd}}$ & $99^{\mathrm{a}}$ & $17^{\text {nop }}$ & $18^{\mathrm{mno}}$ & $35^{\circ}$ & $32^{\text {op }}$ \\
\hline $1^{\text {st }}$ Dec. $\times$ BARI Strawberry- 1 & $87^{\mathrm{kl}}$ & $92^{\mathrm{fgh}}$ & $15^{\text {opq }}$ & $14^{\mathrm{pq}}$ & $32^{\text {op }}$ & $23^{r}$ \\
\hline Level of significance & \multicolumn{2}{|c|}{$* *$} & \multicolumn{2}{|c|}{$* *$} & \multicolumn{2}{|c|}{$* *$} \\
\hline CV $(\%)$ & \multicolumn{2}{|c|}{4.99} & \multicolumn{2}{|c|}{6.80} & \multicolumn{2}{|c|}{2.04} \\
\hline
\end{tabular}


Crops of September planting took longer time for flowering, might be due to interaction of temperature and day length. The genotypes cultivating in Bangladesh are photosensitive and flower in short day. In addition to day length, prevailing temperature after planting might encourage vegetative growth (Chercuitte et al., 1991). Irrespective of genotype, days to flowering of October planting crops in both the years were optimum. This might be due to the fact that October planting crops got sufficient time to attain proper vegetative growth before perceiving photoperiodic response of short days and resulting in floral evacation (Singh et al., 2007). On the other hand, crops of December plantings grew in cool environment and did not get sufficient time to attain proper vegetative growth. Thus, plant age and low ambient temperatures (21.67-21.84 ${ }^{\circ} \mathrm{C}$ and $11.24-11.29^{\circ} \mathrm{C}$, respectively), might have resulted in delaying to flowering. Genotypic responses to the temperature in the growing environment may effect the results (Table 2). This finding corroborated the results of Macit et al. (2007).

Relationship between days to flowering and air temperature. Data revealed between days to flowering and temperature shows that there was a linear but negative relationship (Fig. 1A-D). Days to flowering decreased with the increasing of ambient temperature for each planting time. Crops of 5 different planting dates were exposed in different ambient temperatures during their vegetative and reproductive growth stages. It was revealed from the relationship that with the increase of $1{ }^{\circ} \mathrm{C}$ temperature, the days to flowering decreased about $2.58,3.57,4.26$, and 2.71 days for $1^{\text {st }}$ September, $1^{\text {st }}$ October, $1^{\text {st }}$ November and $1^{\text {st }}$ December planting, respectively. The values of coefficient of determination $\left(\mathrm{R}^{2}\right)$ for the four planting times indicated that more than $97 \%$ of the decrease in days to flowering was due to higher temperature.

Days to harvest. Planting date and genotype interacted significantly in response to days to harvest from flowering (Table 2). 'Sweet Charlie' took the least days to reach harvest when planted in $1^{\text {st }}$ December (13 and 15 days), followed by 'BARI Strawberry-1' when planted in the same date (14 genotype and 15 days) in 2010-11 and 2009-10, respectively. The maximum days to reach harvest maturity occurred in 'FA 008 ' when planted in $1^{\text {st }}$ October (31 and 27 days in 2010-11 and 2009-10, respectively), followed by 'FA 008 ' planted in $1^{\text {st }}$ September (30 days in 2010-11 and 25 days in 200910 crop seasons). Rahman et al. (2014) and Macit et al. (2007), also reported late plantings required least number of days to harvest. Fruit set of late planting occurred in lower ambient temperatures which might experience high temperature during maturity. High temperature might induce shortening of developmental phases (Singh et al., 2007).
(A)

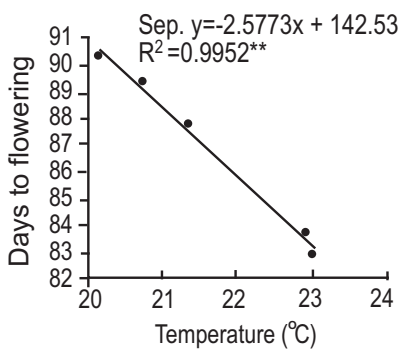

(C)

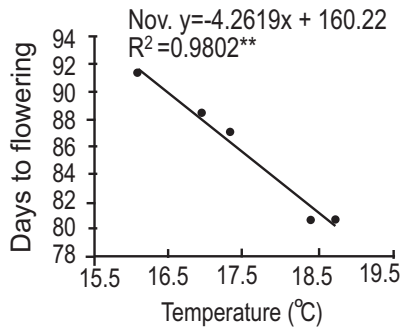

(B)

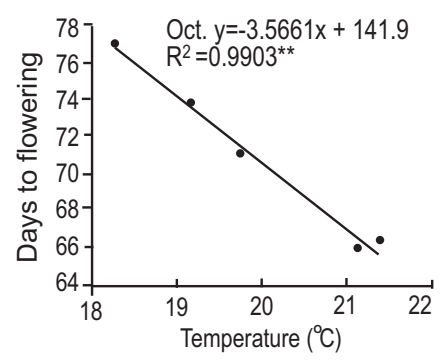

(D)

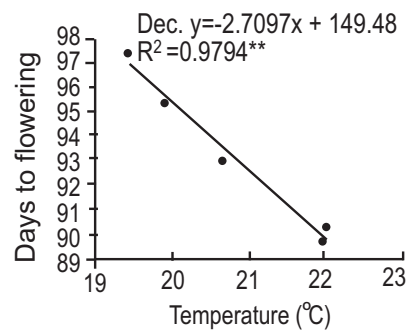

Fig. 1(A-D). Relationship between air temperature and days to flowering for each time of planting when interacted with genotypes (A for $1^{\text {st }}$ September, $\mathrm{B}$ for $1^{\text {st }}$ October, $\mathrm{C}$ for $1^{\text {st }}$ November and $\mathrm{D}$ for $1^{\text {st }}$ December). 
Harvest duration. Longer harvest duration was recorded in September planting which was followed by October planting. The shortest harvest duration was recorded in December planting (Table 2). The longest harvest duration was recorded in 'FA 005' (94 and 98 days), followed by 'Camarosa' (90 and 97 days) and 'Festival' (88 and 93 days), planted on $1^{\text {st }}$ September in 2009-10 and 201011 , respectively. 'Sweet Charlie' planted on $1^{\text {st }}$ December exhibited the shortest harvest duration in both the years (32 days in 2009-10 and 21 days in 2010-11).

Crops of earlier planting dates took the maximum time for fruiting, while late planting crops took less time for fruiting. Ideal temperature and day length of late planting crops might favour early flowering. (Maurer and Umeda, 1999). However, genotypic interaction with temperature were observed in respect of harvest duration (Macit et al., 2007).

Fruits per plant. Number of fruits per plant was highest in the crop planted in October and lowest in December planted crop (Table 3).' Sweet Charlie' planted in $1^{\text {st }}$ October produced the maximum fruits/plant (40 fruits/ plant in 2009-10 and 38 fruits/plant in 2010-11) followed by 'Festival' (37 and 34 fruits/plant in 2009-10 and 2010-11, respectively), when planted in the same date. In both years, BARI Strawberry-1 when planted on $1^{\text {st }}$ December produced minimum fruits/plant (13 in 200910 and 11 in 2010-11). These results are consistent with the findings of Lewis (2003), who reported decline in number of fruits/plant with delayed in planting times. This might be due to the fact that earlier plants were exposed to favourable environment for vegetative growth and subsequently floral signals might be received in November (Table 1). Chercuitte et al. (1991) also explained that early planted strawberry plants produced more fruits than late planted plants.

October planting crops attained optimum age and size due to proper vegetative growth and thus achieved the maturity to respond the change of day length for flowering. September planting crops passed a longer vegetative growth period than that of October planting crop and produced a large number of leaves. During reproductive phase, leaves acted as sink and antagonistic for flowering. On the other hand, November and December plantings had less time for vegetative growth and thus

Table 3. Interaction effect of planting time and genotypes on yield and yield contributing characters of strawberry at 2009-10 and 2010-11

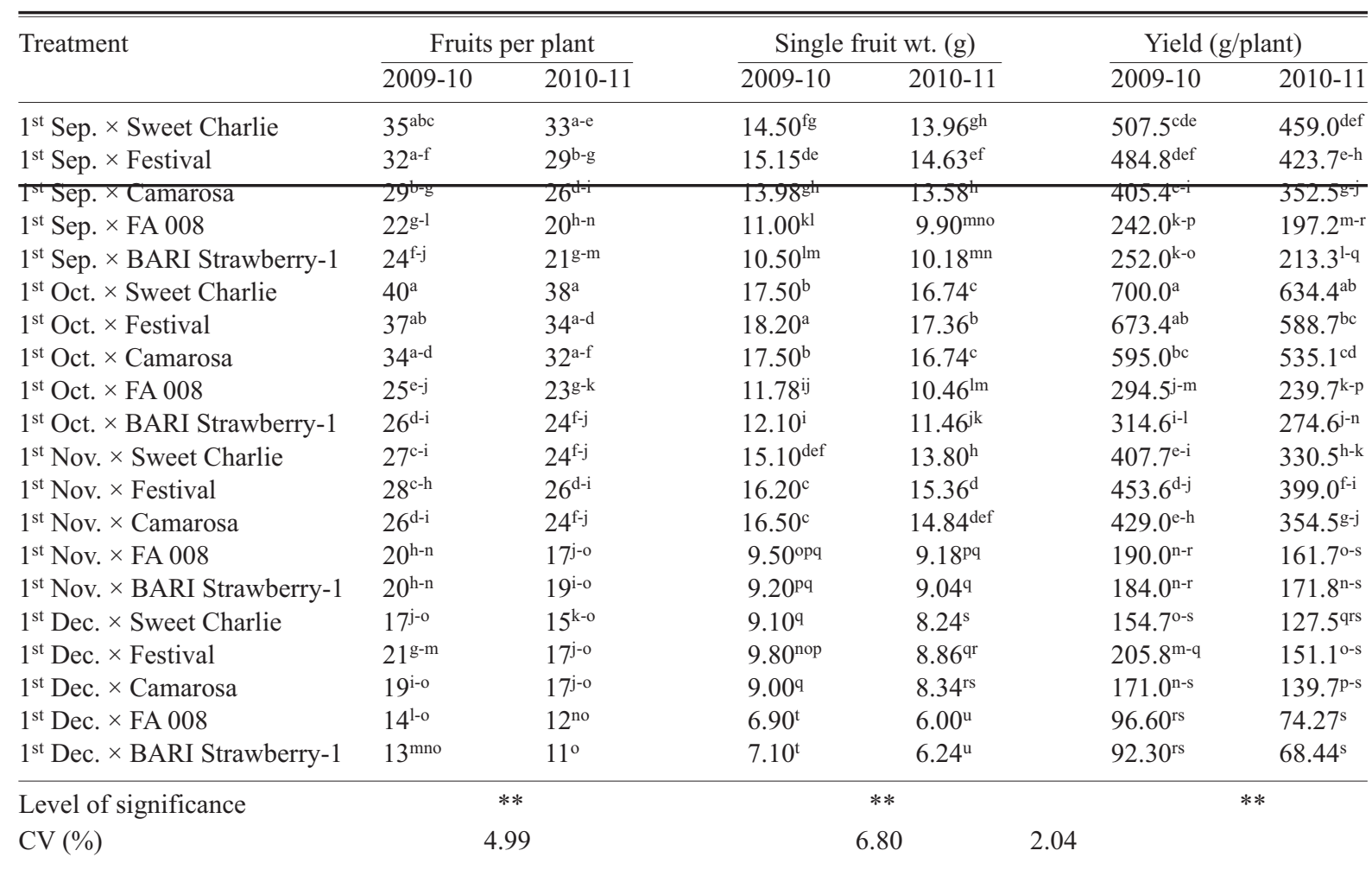


delayed in attaining physiological maturity to respond floral induction of short days. The very early planted crops become more vigorous in growth and this subsequently alter $\mathrm{C}: \mathrm{N}$ ration which hindered flower bud differentiation and thus occurred less production, and lower number of fruits/plant (Chercuitte et al., 1991).

Fruit weight. Fruits of 'Festival', 'Sweet Charlie' and 'Camarosa' of October planting crops weighed maximum (18.20 g in 2009-10 and 17.36 g in 2010-11), (17.50 g and $16.74 \mathrm{~g}$ in 2009-10 and 2010-11, respectively). FA 008 planted in December yielded fruit with lowest weight $(6.90 \mathrm{~g})$ in $2009-10$ and $(6.00 \mathrm{~g})$ in 2010-11 (Table 3). Shortening of developmental phases induced by high temperature, reduced light perception over the shortened life cycle and perturbation of the processes associated with plant carbon balance have resulted in small fruit size. On the other hand, fruit of September planting crops, had optimum time for physiological development (Rahman et al., 2014; Singh et al., 2007). Heat stress also reduced the accumulation of sucrose and ascorbic acids and thus affected fruit quality negatively (Hassan et al., 2000).

Yield per plant. 'Sweet Charlie' planted in October yielded maximum fruits per plant consistently in both the years. Statistically similar trend of results were followed by 'Festival' (673.4 and $588.7 \mathrm{~g}$ per plant in
2009-10 and 2010-11, respectively) and 'Camarosa' (595.0 and 535.1 g per plant in 2009-10 and 2010-11, respectively), planted on the same date, 'Festival' and 'Camarosa' planted in December produced the minimum fruits per plant (Table 3). 'BARI Strawberry-1' had the minimum fruit/plant when planting on $1^{\text {st }}$ December (Table 3). This might be due to sensitivity of the genotype to the planting dates. In a study of planting time and yield of strawberry Chercuitte et al. (1991) reported that the cultivar 'Kent' produced the highest yield when planted in early May and lowest when planted in August in Quebec, Canada. Chandler et al. (1991) found that 'Dover' strawberry produced its highest fruit yield when planted early, while 'Selva', 'FL-83-37' and 'FL 87-210' were less sensitive to planting time and produced more or less similar yield.

Relationship between yield per plant and air temperature. The result revealed a significant negative relationship between yield per plant and temperature (Fig. 2A-D). Yield per plant was maximum in September and $1^{\text {st }}$ October planting crops when temperature ranges from 20 to $23{ }^{\circ} \mathrm{C}$ and $18-21{ }^{\circ} \mathrm{C}$, respectively. It was observed from the regression equations for $1^{\text {st }}$ November and $1^{\text {st }}$ December for every increase of $1{ }^{\circ} \mathrm{C}$ temperature, the yield/plant was decreased about $99.8 \mathrm{~g}$ and $34.1 \mathrm{~g}$, respectively.

(B)

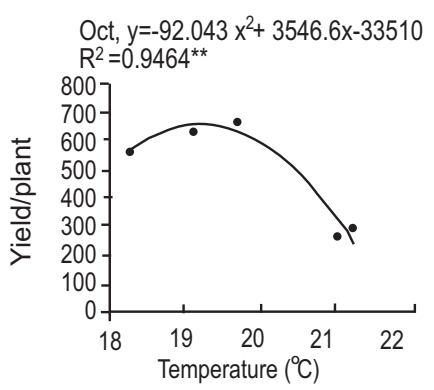

(C)
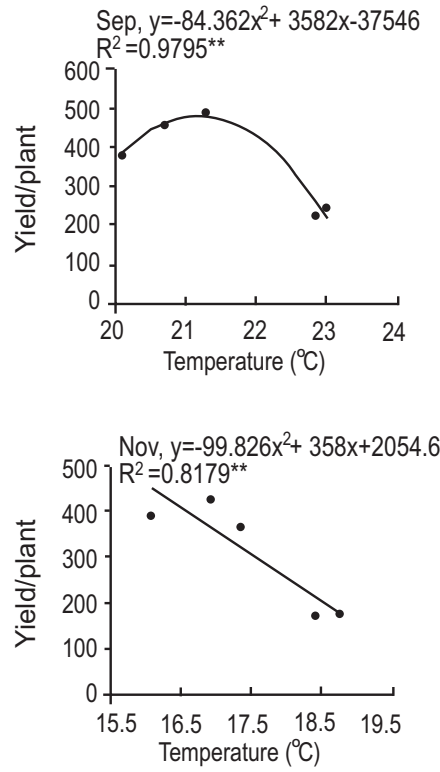

(D)

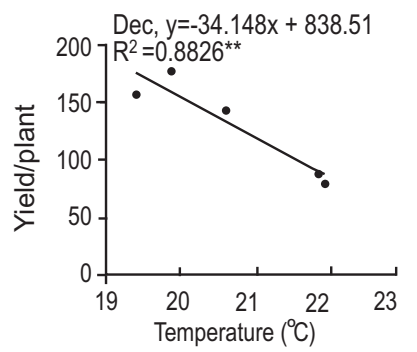

Fig. 2(A-D). Relationship between air temperature and yield per plant for each time of planting when interacted with genotypes (A for $1^{\text {st }}$ September, B for $1^{\text {st }}$ October, C for $1^{\text {st }}$ November and D for $1^{\text {st }}$ December). 


\section{Conclusion}

Considering phenology, yield contributing characters, and yield irrespective of annual effects, planting on $1^{\text {st }}$ October was found to be the most suitable for strawberry cultivation under subtropical conditions found in Bangladesh. 'Sweet Charlie' was found to be superior in yield and considered the best for early planting, while 'Camarosa' was suitable for later plantings in Bangladesh. 'Festival' was found less sensitive to planting date.

\section{References}

Ahmad, A.R., Uddin, A.S.M.M. 2012. Strawberry production in Bangladesh. In: Book of Abstracts, VII-International Strawberry Symposium. Yun-tao Zhang (ed.), 29 pp., held in 18-22 February, ISHS, Beijing, China.

BARI, 2011. Krishi Projukti Hatboi (Handbook on Agrotechnology), pp. 148-155, $5^{\text {th }}$ edition, Bangladesh Agricultural Research Institute, Gazipur 1701, Bangladesh.

Biscoe, P.V., Gallagher, J.N. 1978. A physiological analysis of cereal yield. I. Production of dry matter. Agricultural Progress, 53: 34-58.

Chandler, C.K., Albregts, E.E., Howard, C.M. 1991. Planting time affects early season strawberry production in West Central Florida. Proceedings of the Florida State Horticultural Society, 140: 227-228.

Chercuitte, L., Sullivan, J.A., Desjardins, Y.D., Bedard, R. 1991. Yield potential and vegetative growth of summer-planted strawberry. Journal of the American Society for Horticultural Science, 116: 930-936.

Darnell, R.L. 2003. Strawberry growth and development. In: The Strawberry, A Book for Growers, Others. N. F. Childers (ed.), pp. 3-11, Dr. Norman F. Childers Publications, Gainesville, Florida, USA.

Hassan, G.I., Godara, A.K., Jitender, K., Huchche, A.D.
Kumar, J. 2000. Effect of different mulches on the yield and quality of 'Oso Grande' strawberry (Fragaria $x$ ananassa). Indian Journal of Agricultural Science, 70: $184-185$.

Lewis, J.C. 2003. A modified "plasticulture" system for strawberries in Nova Scotia. In: The Strawberry, A Book for Growers, Others. N. F. Childers (ed.), pp. 53-62, Dr. Norman F. Childers Publications, Gainesville, Florida, USA.

Macit, I., Koc, A., Guler, S., Deligoz, I. 2007. Yield, quality and nutritional status of organically and conventionally grown strawberry cultivar. Asian Journal of Plant Science, 6: 1131-1136.

Maurer, M.A., Umeda, K. 1999. Influence of cultivar and planting time on strawberry growth and development in the low desert. Vegetable Report. Arizona College of Agriculture. In: http://ag.arizona. edu/ pubs/crops/az1143/

Rahman, M.M., Rahman, M.M., Hossain, M.M., Khaliq, Q.A., Moniruzzaman, M. 2014. Effect of planting time and genotypes on growth, yield and quality of strawberry (Fragaria x ananassa Duch.). Scientia Horticulturae, 167: 56-62.

Russell, D.F., Eisenmith, S.P. 1983. MSTAT-C. Crop Soil Sci. Dept., Machigan State Univ. USA.

Rice, R.P.J. 1990. Effects of cultivar and environmental interactions on runner production, fruit yield and harvest timing of strawberry in Zimbabwe. Acta Horticulturae, 279: 327-332.

Singh, R., Sharma, R.R., Goyal, R.K. 2007. Interactive effects of planting time and mulching on 'Chandler' strawberry (Fragaria x ananassa Duch.). Scientia Horticulturae, 111: 344-351.

Zheng, J., Yang, B., Tuomasjukka, S., Ou, S., Kallio, H. 2009. Effects of latitude and weather conditions on contents of sugars, fruit acids, and ascorbic acid in black currant (Ribes nigrum L.) juice. Journal of Agricultural and Food Chemistry, 57: 2977-2987. 